\title{
Dicentric $\mathrm{X}$ isochromosomes in man
}

\author{
R. T. HOWELL, S. H. ROBERTS, and R. J. BEARD \\ From the Child Health Laboratories, Department of Child Health, University Hospital of Wales, Heath Park, Cardiff
}

Summary. Four cases of Turner's syndrome are presented in which an apparent $\mathrm{X}$ isochromosome $\mathrm{i}(\mathrm{Xq})$ has been found to possess two regions of centromeric heterochromatin. It is suggested that these chromosomes were isodicentric structures capable of functioning as monocentric elements as a result of the inactivation of one centromere. The prevalence of mosaicism is believed to be a consequence of the dicentric nature of these chromosomes, and it is considered possible that a high proportion of $\mathrm{X}$ isochromosomes are structurally dicentric. Banding patterns showed that the exchange site involved in the formation of the dicentric chromosome was different in at least three of the cases.

The possibility that certain $\mathrm{X}$ isochromosomes were dicentric was first postulated by de la Chapelle et al (1966). In 2 of 5 cases investigated they noted that the isochromosome had an apparently elongated centromeric region. In 3 cases they found abnormal anaphase configurations such as bridges, pseudochiasmata, and lagging chromosomes, indicative of the presence of a dicentric chromosome. When de la Chapelle and Stenstrand (1974) reinvestigated the 2 isochromosomes in which the elongated centromeric region had been found, they showed, by C-banding, the presence of 2 regions of centromeric heterochromatin, while in 2 other cases they showed the isochromosomes to be monocentric. Yanagisawa and Yokoyama (1975) and Cohen et al (1975) have reported apparently dicentric $\mathrm{X}$ isochromosomes with $2 \mathrm{C}$-bands, while Distèche et al (1972), Therman et al (1974), and de la Chapelle and Stenstrand (1974) have described very long chromosomes consisting of 2 almost complete $\mathrm{X}$ chromosomes including 2 regions of centromeric heterochromatin.

In 4 females referred to us for chromosome studies because they possessed features of Turner's syndrome, an abnormal large metacentric chromosome was found. In all of these cases, C-banding showed 2 distinct regions of centromeric heterochromatin, and trypsin-Giemsa banding suggested that the abnormal chromosome was structurally isodicentric, $\operatorname{dic}(X)(q t e r \rightarrow$ p $11::$ p $11 \rightarrow$ qter $)$.

Received 29 January 1976.

\section{Methods}

Chromosome preparations were made from peripheral blood lymphocyte cultures of all 4 patients using standard procedures. Preparations from skin fibroblast cultures (Cases 1 and 2) and an ovarian tissue culture (Case 3) were also investigated. Slides were either stained with aceto-orcein in order to examine chromosome morpho logy and to obtain counts, Giemsa-banded using a tryp $-\overline{0}$ sin digestion technique modified from Seabright (1971), or C-banded by a modification of the barium hydroxide method described by Sumner et al (1971).

\section{Clinical features}

The 4 patients all presented certain features typical of Turner's syndrome, which are summarized in Table I.

\section{Cytogenetic studies}

\section{(a) Chromosome counts}

Chromosome counts from orcein stained preparations of the 4 cases are shown in Table II. Mosaicism for the abnormal chromosome was found in Cases 2, 3, and 4. In Case 2, the majority of cells in the blood cultures had a 45,X constitution, while the skin cultures consisted mostly of $46, X, d i c(X)(p 11)$ cells. In Case 3, roughly equal proportions of $45, \mathrm{X}$ and $46, \mathrm{X}, \operatorname{dic}(\mathrm{X})(\mathrm{p} 11)$ cells were observed in the blood cultures, but only $46, \mathrm{X}$,dic (X)(p11) cells were found in the ovarian cultures. In Case 4, complements of $47, X, \operatorname{dic}(X)(p 11), \operatorname{dic}(X)(p 11)$ were found, in addition to $45, X$ and $46, X, \operatorname{dic}(X)(p 11)$.

\section{(b) Structure of abnormal chromosomes}

Orcein-stained preparations. In all 4 cases, the presence of an $\mathrm{X}$ isochromosome was indicated in meta- 
TABLE I

SOME RELEVANT CLINICAL FEATURES OF THE FOUR CASES

\begin{tabular}{|c|c|c|c|c|c|c|c|c|c|c|c|}
\hline $\begin{array}{l}\text { Case } \\
\text { No. }\end{array}$ & $\begin{array}{l}\text { Reason for } \\
\text { Investigation }\end{array}$ & $\begin{array}{l}\text { Age at } \\
\text { Investi- } \\
\text { gation } \\
(y)\end{array}$ & $\underset{(\mathrm{cm})}{\text { Height }}$ & $\underset{(\mathrm{kg})}{\text { Weight }}$ & $\begin{array}{l}\text { Intelli- } \\
\text { gence }\end{array}$ & $\begin{array}{l}\text { Webbing } \\
\text { of Neck }\end{array}$ & $\begin{array}{l}\text { Secondary } \\
\text { Sexual } \\
\text { Characters }\end{array}$ & $\begin{array}{c}\text { Amenor- } \\
\text { rhoea }\end{array}$ & Gonads & $\begin{array}{l}\text { Serum LH } \\
\text { and FSH } \\
\text { Levels }\end{array}$ & $\begin{array}{l}\text { Other } \\
\text { Features }\end{array}$ \\
\hline 1 & Hypogonadism & 17 & 140 & 60 & Normal & Absent & Absent & Primary & $\begin{array}{l}\text { Not } \\
\text { investi- } \\
\text { gated }\end{array}$ & $\begin{array}{l}\text { LH } 30 I U / 1 \\
\text { FSH } 80 I U / 1\end{array}$ & $\begin{array}{l}\text { Polydac- } \\
\text { tyly; } \\
\text { horse- } \\
\text { shoe } \\
\text { kidney }\end{array}$ \\
\hline 2 & $\begin{array}{l}\text { Short stature; } \\
\text { increased } \\
\text { carrying angle }\end{array}$ & 12 & 132 & 35 & Normal & Present & $\begin{array}{l}\text { (Pre- } \\
\text { pubertal) }\end{array}$ & $\begin{array}{l}\text { (Pre- } \\
\text { pubertal) }\end{array}$ & $\begin{array}{l}\text { Not } \\
\text { investi- } \\
\text { gated }\end{array}$ & $\begin{array}{l}\text { FSH } 19.4 \\
\text { IU/1 }\end{array}$ & $\begin{array}{l}\text { Pigmented } \\
\text { naevi; } \\
\text { emotional } \\
\text { problems }\end{array}$ \\
\hline 3 & $\begin{array}{l}\text { Short stature; } \\
\text { lack of } \\
\text { secondary } \\
\text { sexual } \\
\text { characters }\end{array}$ & 17 & 131 & 41 & Normal & Absent & Absent & Primary & $\begin{array}{l}\text { Streak } \\
\text { ovaries } \\
\text { vestigial } \\
\text { uterus }\end{array}$ & $\begin{array}{l}\text { LH } 501 U / 1 \\
\text { FSH 80IU/1 }\end{array}$ & \\
\hline 4 & $\begin{array}{l}\text { Primary } \\
\text { amenorrhoea }\end{array}$ & 18 & 142 & 58 & Normal & Absent & $\begin{array}{l}\text { Slight } \\
\text { breast } \\
\text { develop- } \\
\text { ment } \\
\text { after } \\
\text { oestrogen } \\
\text { therapy }\end{array}$ & Primary & $\begin{array}{l}\text { Streak } \\
\text { ovaries } \\
\text { vestigial } \\
\text { uterus }\end{array}$ & $\begin{array}{l}\text { Not investi- } \\
\text { gated }\end{array}$ & \\
\hline
\end{tabular}

TABLE II

CHROMOSOME COUNTS FROM THE 4 CASES

\begin{tabular}{|c|c|c|c|c|c|c|}
\hline & & \multicolumn{5}{|c|}{ Number of Mitoses } \\
\hline Case No. & Tissue & $\begin{array}{l}\leqslant 45, \text { random } \\
\text { loss }\end{array}$ & $45, x$ & $46, X, \operatorname{dic}(X)(p 11)$ & $\begin{array}{c}\text { 47,X,dic(X)(p11), } \\
\operatorname{dic}(X)(\mathrm{p} 11)\end{array}$ & Total \\
\hline \multirow{2}{*}{1} & $\int$ Blood & 4 & 0 & 76 & 0 & $80\}$ \\
\hline & $\begin{array}{l}\text { Skin } \\
\text { Blood }\end{array}$ & $\begin{array}{l}2 \\
3\end{array}$ & $\begin{array}{r}0 \\
66\end{array}$ & $\begin{array}{l}10 \\
11\end{array}$ & $\begin{array}{l}0 \\
0\end{array}$ & $12\}^{9}$ \\
\hline 2 & $\begin{array}{l}\text { Skin } \\
\text { Blood }\end{array}$ & $\begin{array}{l}3 \\
3\end{array}$ & $\begin{array}{r}4 \\
40\end{array}$ & $\begin{array}{l}25 \\
57\end{array}$ & $\begin{array}{l}0 \\
0\end{array}$ & $\begin{array}{r}32 \\
100\end{array}$ \\
\hline 3 & $\begin{array}{l}\text { Ovary } \\
\text { Blood }\end{array}$ & $\begin{array}{r}2 \\
11\end{array}$ & $\begin{array}{r}0 \\
17\end{array}$ & $\begin{array}{l}26 \\
72\end{array}$ & $\begin{array}{l}0 \\
5\end{array}$ & $\begin{array}{c}28 \\
105\end{array}$ \\
\hline
\end{tabular}

phases having 46 chromosomes, because there appeared to be $7 \mathrm{~A}$ group and $15 \mathrm{C}$ group chromosomes. In Cases 1,2 , and 3 , the abnormal $\mathrm{X}$ did not have the appearance of a dicentric chromosome. In Case 4, however, it was recognizable in 36 out of 72 cells by its dicentric morphology (Fig. 1A), or the presence of a secondary constriction (Fig. 1B).

C-banded preparations. Three C-banded abnormal X chromosomes from each of the cases are shown in Fig. 2. Two regions of centromeric heterochromatin are clearly indicated in all of the examples. In Cases 1, 2 , and 3 , one $\mathrm{C}$-band was at the centromeric constriction and one was interstitial. The interstitial C-band was often separated into a pair of darkly staining spots, one on each chromatid. In Case 4, the abnormal chromosome sometimes had 2 centromeric constrictions, each with a C-band (Fig. $2 \mathrm{~s}$ and $\mathrm{t}$ ). Fig. $2 \mathrm{u}$ shows 2 abnormal X chromosomes from a cell with 47 chromosomes.

The distance between the C-bands was consistent within a case, but varied between cases.
G-banded preparations. Examples of the abnormal $\mathrm{X}$ chromosome from the 4 cases after trypsinGiemsa treatment are shown in Fig. 2, and diagrams of their banding patterns in Fig. 3. In Cases 1 and 2, the banding pattern was found to be asymmetrical about the centromeric constriction, thus showing that the abnormal chromosomes were not classical isochromosomes. The shorter of the two arms was a normal long arm (Xq), while the longer consisted of a normal Xq with additional material proximal to the centromere. This material included a prominent darkly staining band which was interpreted as representing an interstitial centromeric region because it corresponded in position to the interstitial C-band, and was the same distance from the landmark band Xq21 (Paris Conference, 1971; Fig. $3 \mathrm{~b}$ ) on the abnormal arm as was the normal centromere from the landmark band Xq21 on the normal arm. In Case 2, a narrow dark band was sometimes visible midway between the two centromeric bands (Fig. $2 j$ and k). This band is believed to be equivalent to the fine sub-band occasionally shown by our banding technique 

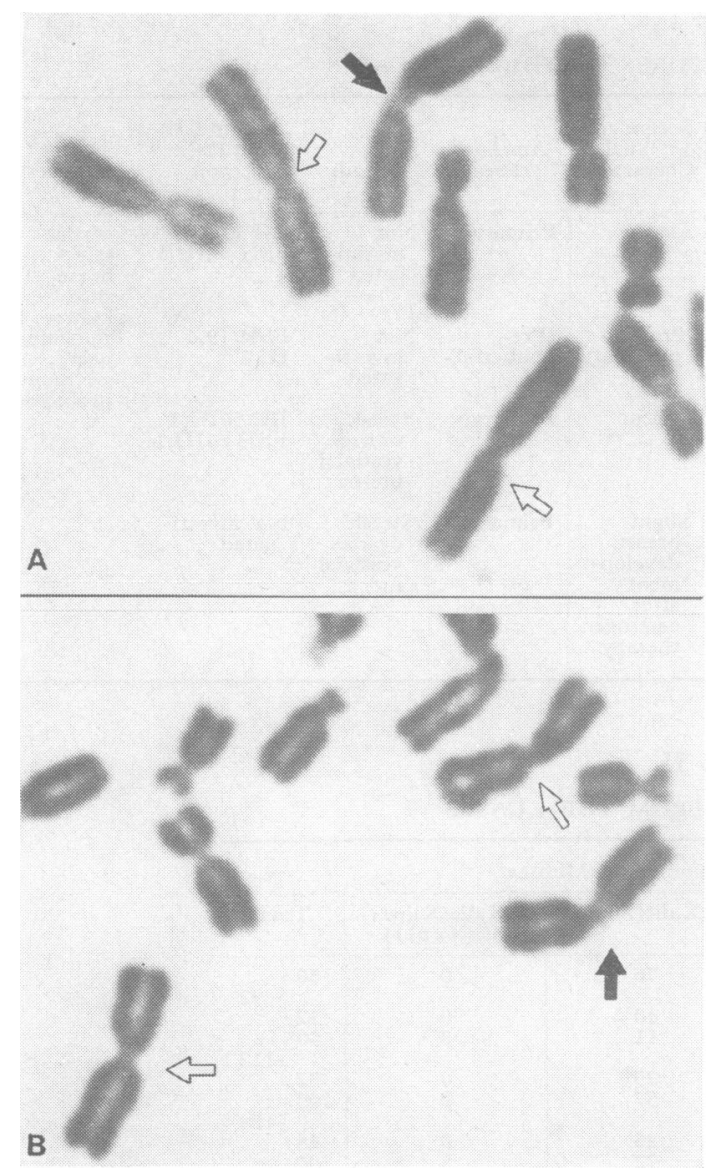

FIG. 1. The morphology of the abnormal $\mathrm{X}$ chromosome in orcein stained preparations from Case 4, showing A) a dicentric appearance and $B$ ) a prominent secondary constriction. The abnormal $X$ is indicated by the black arrow and the homologues of chromosome 3 by open arrows for comparison.

to occur on the proximal part of the short arm of the normal X chromosome (Fig. 2 f, j, and 1; Fig. 3 a).

In Case 3, the abnormal $X$ chromosome could not be readily distinguished by $\mathrm{G}$-banding from a classical isochromosome $\mathrm{Xq}$, because of the close proximity of the two centromeric regions.

In Case 4, the abnormal chromosome was either similar to that in Case 1 (cf. Fig. 2d and 2v) or had 2 centromeric constrictions (Fig. $2 w$ ). Fig. $2 x$ shows the two abnormal $X$ chromosomes from a cell with 47 chromosomes.

\section{Discussion}

C-banding showed that the abnormal X chromosomes described in this report were structurally dicentric, and G-banding showed that each arm distal to the centromeric bands consisted of the long arm of an $\mathrm{X}$ chromosome. Chromosomes of this kind may be referred to as isodicentric (Darlington and Wylie, 1953), and their most probable mode of origin is by an isochromatid break of the short arm of an X chromosome close to the centromere, with sister union of the chromatids proximal to the centromere. Their formation in other ways such as translocation between two $\mathrm{X}$ chromosomes, or meiotic crossover within a paracentric inversion loop cannot, however, be discounted. It is probable that the other abnormal $\mathbf{X}$ chromosomes with 2 C-bands already reported (Distèche et al, 1972; de la Chapelle and Stenstrand, 1974; Therman et al, 1974; Yanagisawa and Yokoyama, 1975; Cohen et al, 1975) were similarly isodicentric, but formed by breakage and sister union at different sites.

In the present cases, banding showed that different break points were involved in the formation of the abnormal chromosomes. These are shown in Fig. 3. In G-banded preparations of Case 2, the narrow dark band sometimes visible midway between the 2 centromeric bands (Fig. 2j and k; Fig. 3) indicated that the break point was further from the centromere than in the other cases where this band was absent. In Case 3, C-banding showed that the break point was closer to the centromere than in the other cases. The length of the intercentric region in Cases 1 and 4 was similar, indicating that, in thes 2 cases, the break points were in a similar position?

It is generally accepted that most dicentric chro mosomes are unstable for two reasons. Firstly, the rearrangement of chromosome material and subsequent loss of the acentric fragment results in an imbalance which must be compatible with survival for the dicentric chromosome to persist. (In the 4 present cases, the imbalance of $X$ chromosome material gives rise to features of Turner's syndrome -see Table I.) Secondly, there is a tendency for anaphase bridge formation which may lead to breakage or non-disjunction of the dicentric chromosome. Nevertheless, in addition to the previously reported stable dicentric $\mathrm{X}$ chromosomes already mentioned, a number of stable dicentric $\mathrm{Y}$ chromosomes (inter alia Cohen et al, 1973) and stable dicentric autosomes (Niebuhr, 1972a, b; Subrt et al, 1971; Warburton et al, 1973; Roberts et al, 1977) have also been described in man. The survival of $46, X, \operatorname{dic}(X)(p 11)$ cell lines shows that the dicentric chromosomes in the present report were likewise stable. As these chromosomes were probably isodicentric, their two centromeres were probably identical in origin, and it, therefore, appears that, in each case, one centromere behaved abnormally so that the chromosome was able to function as a monocentric element. The separation of the inter- 


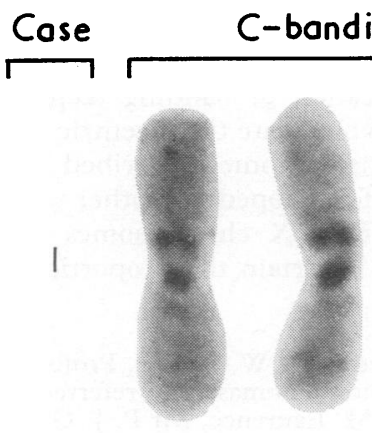

a

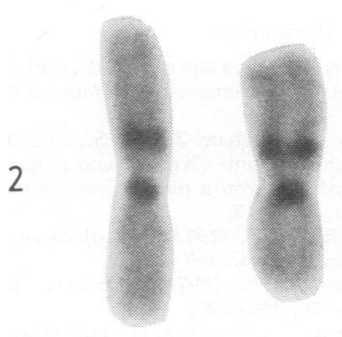

9

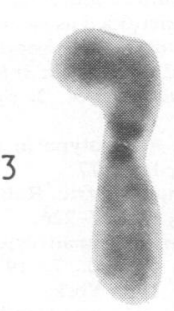

$m$

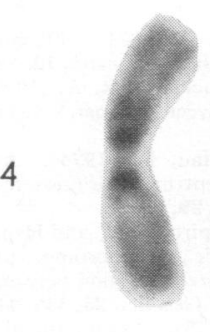

S

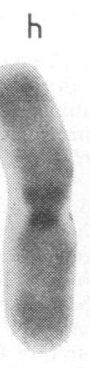

n

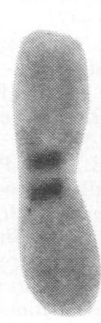

t

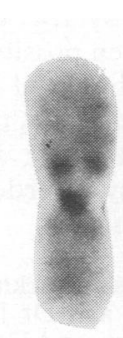

c
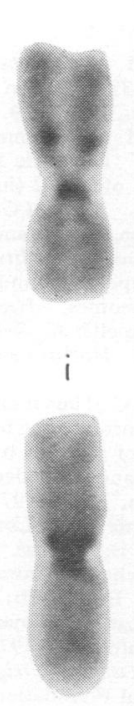

O

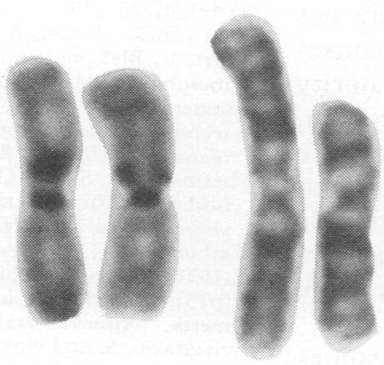

U

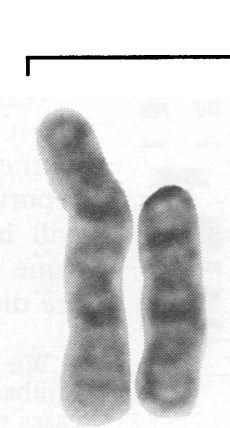

d

\section{G-banding}

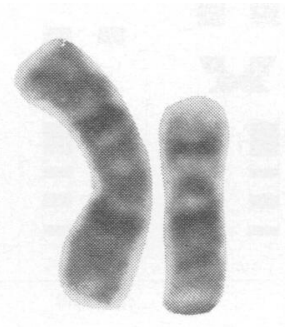

e

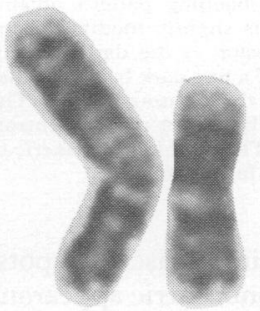

k

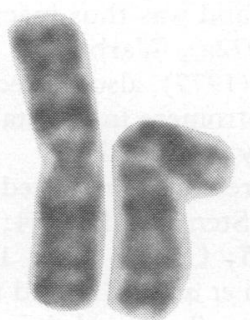

१
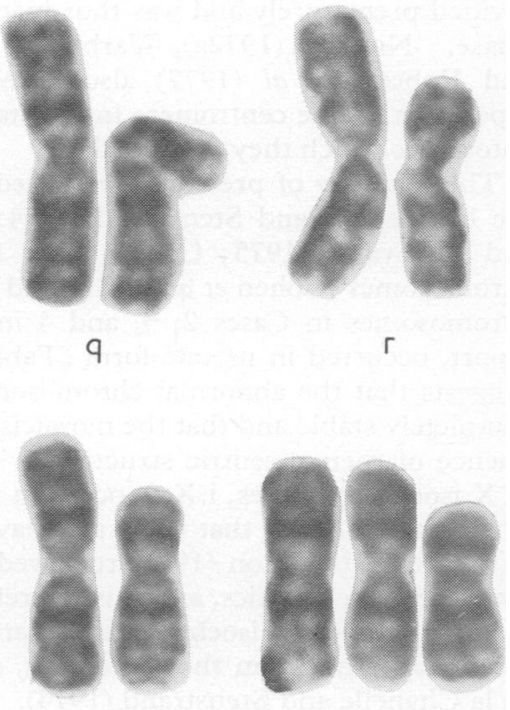

x

FIG. 2. The abnormal $X$ chromosome in the 4 cases after either $\mathrm{C}$-banding or G-banding. The C-banded examples show variation in the appearance of the interstitial centromere. In the $G$-banded examples the abnormal $X$ is shown to the left of the normal $X$ from the same cell. $u$ and $x$ are from cells with 47 chromosomes. The interstitial centromeric region, where recognizable, is shown uppermost. 


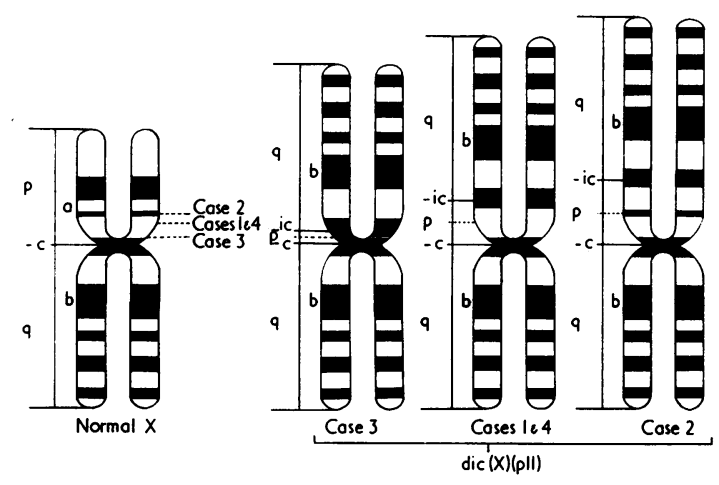

FIG. 3. Diagram to show the position of the break points involved in the formation of the dicentric $\mathbf{X}$ chromosomes. The break points are indicated by broken lines.

The diagram represents the banding pattern obtained by our trypsin-Giemsa technique and is slightly modified from the Paris Conference (1971) by the extension of the dark band through the centromere, and the inclusion of a fine dark band (labelled a) on the proximal part of the short arm of the $X$ chromosome. The landmark band on the long arm is labelled $b$; $c$ is the normal centromere and ic is the interstitial centromere. The double centromeric constriction frequently seen in Case 4 is not indicated.

stitial C-band into a pair of discrete spots (Fig. 2 $c, h, i$, and $u$ ) and the monocentric appearance of the chromosome in orcein-stained preparations of Cases 1,2 , and 3 , indicate that the interstitial centromere divided prematurely and was thus inactive at metaphase. Niebuhr (1972a), Warburton et al (1973), and Roberts et al (1977) also noted premature separation of one centromere in the stable dicentric autosomes which they described.

The majority of previously reported dicentric $\mathbf{X}$ (de la Chapelle and Stenstrand, 1974; Yanagisawa and Yokoyama, 1975; Cohen et al, 1975) and Y chromosomes (Cohen et al, 1973), and the dicentric chromosomes in Cases 2, 3, and 4 in the present report, occurred in mosaic form (Table II). This suggests that the abnormal chromosomes were not completely stable and that the mosaicism is a consequence of their dicentric structure. The majority of $\mathrm{X}$ isochromosomes, $\mathrm{i}(\mathrm{Xq})$, occur in mosaic form, which may indicate that these also have a dicentric structure. Hamerton (1971) reviewed 50 cases, of which 38 were mosaics, and it is, therefore, possible that $75 \%$ or more $X$ isochromosomes are structurally dicentric, rather than the 10 to $15 \%$ suggested by de la Chapelle and Stenstrand (1974).

It is interesting to note that $\operatorname{dic}(\mathbf{X p})$ chromosomes formed by breakage and sister union in the proximal region of the long arm might be morphologically similar to a normal $\mathrm{X}$ chromosome and be overlooked unless the interstitial centromere were visible.

Only by the application of banding techniques has it been possible to elucidate the dicentric nature of the abnormal $\mathrm{X}$ chromosomes described in this report, and it is, therefore, hoped that other workers will investigate abnormal $\mathrm{X}$ chromosomes in the same way in order to ascertain the proportion that are dicentric.

We wish to acknowledge Dr W. Davies, Professor B. Hibbard, and Dr J. Picton Thomas, who referred the 4 cases to us, and Dr K. M. Laurence, Mr P. J. Gregory, and Dr D. P. Duckett, for their help and advice.

\section{REFERENCES}

Cohen, M. M., MacGillivray, M. H., Capraro, V. J., and Aceto, T. A. (1973). Human dicentric Y chromosomes. Fournal of Medical Genetics, 10, 74-79.

Cohen, M. M., Rosenmann, A., Hacham-Zadeh, S., and Dahan, S. (1975). Dicentric X isochromosome (Xqidic) and pericentric inversion of No. 2 (inv(2)(p15q21)) in a patient with gonadal dysgenesis. Clinical Genetics, 8, 11-17.

Darlington, C. D. and Wylie, A. P. (1953). A dicentric cycle in Narcissus. Heredity, 6, Suppl. Vol., 197-213.

de la Chapelle, A. and Stenstrand, K. (1974). Dicentric human X chromosomes. Hereditas, 76, 259-268.

de la Chapelle, A., Wennström, J., Hortling, H., and Ockey, C. H. (1966). Isochromosome $X$ in man, Part I. Hereditas, 54, 260276.

Distèche, C., Hagemeijer, A., Frederic, J., and Progneaux, D. (1972). An abnormal large human chromosome identified as an end-to-end $O$ fusion of two X's by combined results of the new banding tech niques and microdensitometry. Clinical Genetics, 3, 388-395.

Hamerton, J. L. (1971). Human Cytogenetics, Vol. 2, pp. 86-88. Academic Press, London.

Niebuhr, E. (1972a). A 45,XX,5-13-dic + karyotype in a case of cri-du-chat syndrome. Cytogenetics, 11, 165-177.

Niebuhr, E. (1972b). Dicentric and monocentric Robertsonian translocations in man. Human Genetics, 16, 217-226.

Paris Conference (1971). Standardization in human cytogenetics. Birth Defects: Original Article Series, 8, No. 7, 1972. The National Foundation-March of Dimes, New York.

Roberts, S. H., Howell, R. T., Laurence, K. M., and Heathcote, M. E. (1977). A stable dicentric autosome, $\operatorname{tdic}(8: 22)(\mathrm{p} 23: \mathrm{p} 13)$, in a mentally retarded girl. Fournal of Medical Genetics (in press).

Seabright, M. (1971). A rapid banding technique for human chromosomes. Lancet, 2, 971-972.

Subrt, I., Blehová, B., and Taborský, O. (1971). Dicentric chromosome due to an unusual fusion. Humangenetik, 12, 136-141.

Sumner, A. T., Evans, H. J., and Buckland, R. A. (1971). New technique for distinguishing between human chromosomes. Nature New Biology, 232, 31-32.

Therman, E., Sarto, G. E., and Patau, K. (1974). Apparently isodicentric but functionally monocentric $\mathbf{X}$ chromosome in man. American fournal of Human Genetics, 26, 83-92.

Warburton, D., Henderson, A. S., Shapiro, L. R., and Hsu, L. Y. F. (1973). A stable human dicentric chromosome, tdic(12:14) (p13:p13) including an intercalary satellite region between centromeres. American fournal of Human Genetics, 25, 439-445.

Yanagisawa, S. and Yokoyama, H. (1975). Symptoms of Turner's syndrome and interstitial heterochromatin in $\mathrm{i}(\mathrm{Xq})$. Clinical Genetics, 7, 299-303. 